\title{
Hemoglobin H Disease and Beta Thalassemia Major Demonstrated Higher Leucocytic DNA Damage
}

\author{
Yim Tong Szeto, Phyllis Lok Yin Ho, Tommy Tsz Hin Kong
}

\section{ABSTRACT}

Hemoglobin $H$ disease and beta thalassemia major are the more severe forms of thalassemia with frequent blood transfusion may be required. Iron chelation therapy is usually needed with blood transfusion to avoid iron overload. Oxidative stress mediated by excess iron via Fenton reaction may contribute to cellular DNA damage. This study was to investigate whether $\mathrm{HbH}$ and beta thalassemia major patients were suffered from higher oxidative stress in leucocytes. Comet assay was performed to investigate the DNA damage of 40 normal subjects, 40 hemoglobin $H$ disease patients and beta thalassemia major patients. The UV-induced DNA damages of leucocytes were measured. The comet scores calculated by visual scoring under light microscope represented DNA damage. The mean \pm standard deviation comet score for normal subjects; $\mathrm{HbH}$ disease and beta thalassemia major were $262.9 \pm 8.1,293.9 \pm 15.4$ and $293.5 \pm 7.2$ respectively. Results showed that both $\mathrm{HbH}$ disease and beta thalassemia major patients had higher DNA damage in white blood cells.

Keywords: Comet assay, DNA damage, iron, leucocyte, thalassemia.

\author{
Published Online: December 21, 2021 \\ ISSN: $2684-5199$ \\ DOI : 10.24018 /ejbio.2021.2.6.307 \\ Y. T. Szeto* \\ Hong Kong Baptist University, Hong \\ Kong. \\ (e-mail: ytszeto@alumni.vtc.edu.hk) \\ P. L. Y. Ho \\ Tuen Mun Hospital, Hong Kong. \\ (e-mail: yujip411@gmail.com) \\ T. T. H. Kong \\ Tuen Mun Hospital, Hong Kong. \\ (e-mail: kth.tommy@ gmail.com) \\ *Corresponding Author
}

\section{INTRODUCTION}

Thalassemia is the genetic disorder characterized by the defect in the synthesis of one or more globin chains that form the hemoglobin tetramer. A normal adult hemoglobin consists of two pairs of globin chains Hoffbrand \& Moss (2016). Hemoglobin A is the major hemoglobin found in adults which has two $\alpha$ chains and two $\beta$ chains. Alpha globin chains are synthesized by two $\alpha$ genes, $\alpha 1$ and $\alpha 2$ on chromosome 16 , while $\beta$ globin chains are synthesized by a single gene on chromosome 11 Brancaleoni et al. (2016). When the production of one type of globin chains is decreased or absent, insufficient amount of normally structured globin chains will result. The two major types of thalassemia are $\alpha$ thalassemia and $\beta$ thalassemia. The reduced production of $\alpha$ globin chain leads to $\alpha$ thalassemia, while the reduced production of $\beta$ globin chain causes $\beta$ thalassemia Tari et al. (2018).

Most of the $\beta$ thalassemia are the result of point mutation, leading to the decrease and/or absence of $\beta$ chain production while the alpha chain synthesis is not affected. Excess of alpha globin chains accumulate and precipitate in red cell precursors in the bone marrow and form inclusion bodies Tari et al. (2018). These inclusion bodies are responsible for the extensive intramedullary destruction of the red cell precursors and thus the ineffective erythropoiesis in $\beta$ thalassemia. $\beta$ thalassemia can be classified into 3 subgroups namely $\beta$ thalassemia major, intermedia and minor. $\beta$ thalassemia major and intermedia are involved in 2 mutated genes while $\beta$ thalassemia minor is involved in 1 mutated gene Hoffbrand $\&$ Moss (2016). Treatments for $\beta$ thalassemia can be scheduled red cell transfusion for severe cases, for $\beta$ thalassemia minor, it is not necessary for blood transfusion Tari et al. (2018).

While $\alpha$ thalassemia is the result of gene deletion, it happens when there are one or more alpha globin genes deleted Bain et al. (2011). The deletion of alpha globin gene causes decreased production of alpha-globin chains, excess beta-globin chains are then combined with each other to form hemoglobin $\mathrm{H}$. When there are 3 and 4 alpha globin genes deleted, $\mathrm{Hb} \mathrm{H}$ disease and $\mathrm{Hb}$ Bart's disease are resulted respectively Angastiniotis \& Lobitz (2019). Hb H precipitates on the red blood cell surface, which shows multiple bluegreen spherical inclusion by new methylene blue Bain et al. (2011). Patients with $\mathrm{Hb} \mathrm{H}$ are usually asymptomatic. While under stress such as infection, pregnancy and drug exposure, severe anemic symptoms may result. $\mathrm{Hb} \mathrm{H}$ disease is associated with iron overload. It has been suggested that iron absorption significantly increase in $\mathrm{Hb} \mathrm{H}$ patients Tari et al. 2018).

$\mathrm{Hb} \mathrm{H}$ disease is a severe form of alpha thalassemia. The prevalence is approximately 1 in a million in Northern Europe and North America while there are about $4-20$ in 1000 individuals suffer in Middle East, Southeast Asia and Mediterranean countries Piel \& Weatherall (2014). Hb H disease patients develop moderately severe anemia as the imbalance of the globin chain and excess beta-globin chain form $\mathrm{Hb} \mathrm{H}$. Most of the patients do not require transfusion unless in severely anemic cases. Patients suffering from 
thalassemia experience iron overload even with no transfusion Chen et al. (2000). Iron overload in thalassemia is suggested to be the result of increased gastrointestinal iron absorption which is triggered by chronic anemia Liu et al. (2016). It is also a source of oxidative stress, which leads to DNA damage. Iron facilitates the formation of free radical via Fenton reaction. It is anticipated that $\mathrm{Hb} \mathrm{H}$ disease and beta thalassemia major would have higher cellular DNA damage. In the current study, leucocytic DNA damages of $\mathrm{Hb} \mathrm{H}$ disease and beta thalassemia major patients would be compared with normal subjects.

\section{METHODS}

Sodium chloride $(\mathrm{NaCl})$, sodium hydroxide $(\mathrm{NaOH})$, disodium ethylenediaminetetraacetic acid dehydrate ( $\mathrm{Na}_{2}$ EDTA), Triton $\mathrm{X}-100$, low melting point agarose, dimethylsulfoxide (DMSO) and standard agarose were purchased from Sigma-Aldrich (St. Louis, MO). Giemsa stain was purchased from Merck (Darmstadt, Germany). UV transilluminator, Spectroline ENF-280C/ FBE, 8 Watts was from Spectronics corporations (Melville, NY). Conventional light microscope Nikon (model ECLIPSE Ci-S, Melville, NY) was used for comet assay grading.

Forty blood samples from patient with $\mathrm{Hb} \mathrm{H}$ disease, 40 from beta thalassemia major and 40 from normal subjects were collected from local population. The control group was healthy individuals (27 females and 13 males) which had not been diagnosed with any hematological disorders. Forty subjects (27 females and 13 males) were diagnosed with $\mathrm{Hb}$ $\mathrm{H}$ disease and 40 patients suffered from thalassemia major (25 females and 15 males). Demographics of the subjects are shown in Table I. Venous bloods were taken in the EDTA blood tube and kept at $-70^{\circ} \mathrm{C}$ until testing within 2 months. Samples were thawed at $37{ }^{\circ} \mathrm{C}$ water bath before proceeding to comet assay.

Clean glass microscope slides were dipped into a small beaker with $1 \%$ melted standard agarose. Excess agarose was drained off and the back of the slides was cleaned. The slides were dried in the oven and stored in box at room temperature. One percent low melting point agarose was prepared and kept at $40{ }^{\circ} \mathrm{C}$ water bath to keep molten state. Ten $\mu \mathrm{L}$ of whole blood and $170 \mu \mathrm{L}$ of $1 \%$ low melting point agarose was transferred into a $1.5 \mathrm{~mL}$ microtube and were well mixed. Eighty-five $\mu \mathrm{L}$ of the mixture was then transferred onto a coated microscope slide and covered with $18 \times 18 \mathrm{~mm}$ coverslip to flatten the gel. The slides were chilled at $4{ }^{\circ} \mathrm{C}$ for solidification for about 5 minutes. The coverslips were removed after the gel set. Each microscope slide could accommodate two gels and one slide were prepared for each sample. Oxidative stress was applied to the cells by irradiating the slides under the UVB light for 2 minutes to damage the DNA. The distance between the slides and the light source was set at $6 \mathrm{~cm}$. Lysis solution $(2.5 \mathrm{~mol} / \mathrm{L} \mathrm{NaCl}$, $0.1 \mathrm{~mol} / \mathrm{L} \mathrm{Na}{ }_{2} \mathrm{EDTA}, 10 \mathrm{mmol} / \mathrm{L}$ Tris, $\mathrm{pH}$ 10) was prepared and refrigerated at $4{ }^{\circ} \mathrm{C}$. Five hundred $\mu \mathrm{L}$ Triton $\mathrm{X}-100$ and $5 \mathrm{~mL}$ DMSO were mixed with $50 \mathrm{~mL}$ cold lysis solution just before use. The slides were placed into a Coplin jar with the lysis solution at $4{ }^{\circ} \mathrm{C}$ for 1 hour in dark. After lysing, the slides proceeded to DNA unwinding and breaking process by immersed in electrophoresis solution $(0.3 \mathrm{~mol} / \mathrm{L} \mathrm{NaOH}$ and
$1 \mathrm{mmol} / \mathrm{L} \mathrm{Na} 2 \mathrm{EDTA}$ with $\mathrm{pH}>13$ and $4{ }^{\circ} \mathrm{C}$ ) for 10 minutes twice. The electrophoresis solution was kept at $4{ }^{\circ} \mathrm{C}$ before use. The slides were placed onto the platform of the electrophoresis tank and covered with electrophoresis solution. The electrophoresis ran for 30 minutes at $25 \mathrm{~V}$, and the current was set at $0.30 \mathrm{~A}$ by adjusting the level of solution. Ice packs were placed under the tank for cooling purpose. The slides were removed and placed in the distilled water twice for 5 minutes each. They were dried at $37^{\circ} \mathrm{C}$ for 30 minutes. The slides were fixed with $70 \%$ ethanol for 10 minutes. The working Giemsa stain solution was prepared by 1 part of stock Giemsa stain and 1 part of $\mathrm{pH} 6.8$ phosphate buffer. The working Giemsa stain solution was filtered by Whatman No. 1 filter paper before the staining process. The slides were stained for 30 minutes. After the staining process, the slides were rinsed by the $\mathrm{pH} 6.8$ phosphate buffer and dried Osipov et al. (2014).

DNA damage of leucocytes were classified into five grades, where grade 0 indicated no DNA damage and grade 4 indicated a fully damaged nucleus with long tail. The DNA damage score was calculated by as follow:

DNA damage score $=(0 x G 0)+(1 x G 1)+(2 x G 2)+(3 x G 3)$ $+(4 \mathrm{xG} 4)$ Szeto \& Chan (2021).

G0 was the number of cells without DNA damage while G4 was the number of cells with largest damage. One hundred cells per gel were scored and hence the maximum score of a gel could be 400 .

The One-way ANOVA followed by Dunnett's Multiple Comparison test were used for statistical analysis (Prism 5.0, GraphPad Software Inc). P value less and 0.05 was considered as statistically significant.

\section{REsults}

The demographics summary and the results of the 120 samples were shown in Table I. The average age and standard derivation of normal subjects, $\mathrm{Hb} \mathrm{H}$ and beta thalassemia major patients and were $56.6 \pm 22.1,56.0 \pm 19.3$ and $55.1 \pm 21.5$ years old respectively. The mean ( \pm standard deviation) comet score of control group, $\mathrm{Hb} \mathrm{H}$ patients and $\beta$ thalassemia major patients were $262.9( \pm 8.1) ; 293.9( \pm 15.4)$ and 293.5 $( \pm 7.2)$, respectively. Higher DNA damage in both types of thalassemia was seen (Fig. 1). Results agreed with our pilot study which involved fewer number of subjects [10].

TABLE I: DEMOGRAPHICS AND COMET SCORES OF THALASSEMIA PATIENTS AND NORMAL SUBJECTS

\begin{tabular}{cccc}
\hline \hline Variables & $\begin{array}{c}\text { Normal } \\
\text { subject }\end{array}$ & Hb H disease & $\begin{array}{c}\text { Beta } \\
\text { thalassemia } \\
\text { major }\end{array}$ \\
\hline \hline Age range $(y r)$ & $12-89$ & $12-83$ & $13-89$ \\
Mean age \pm SD $(y r)$ & $56.6 \pm 22.1$ & $56.0 \pm 19.3$ & $55.1 \pm 21.5$ \\
Male / Female & $13 / 27$ & $13 / 27$ & $15 / 25$ \\
Mean \pm SD comet & $262.9 \pm 8.1$ & $293.9 \pm 15.4$ & $293.5 \pm 7.2$ \\
score & & & \\
\hline \hline
\end{tabular}




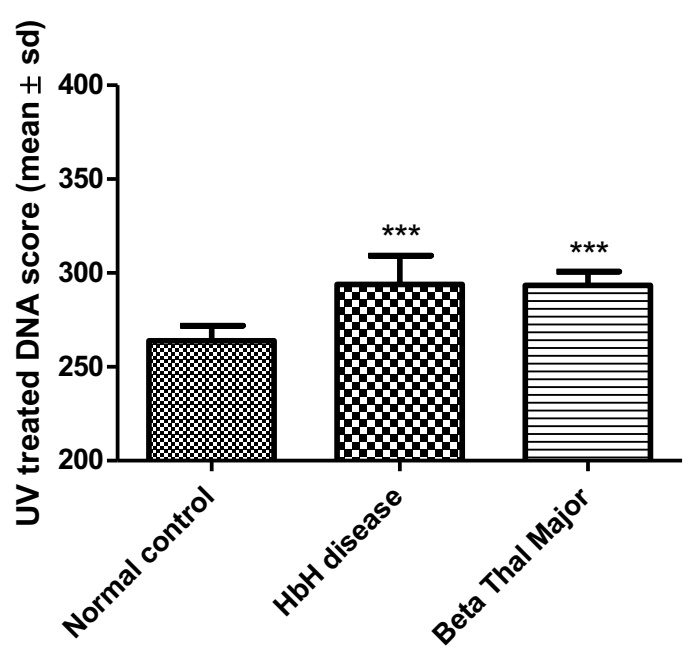

Fig. 1. Mean comet score \pm 1 standard deviation of normal subjects; $\mathrm{HbH}$ disease and beta thalassemia major patients. Statistically significant differences were seen between thalassemia and normal subjects. One-way ANOVA followed by Dunnett's multiple comparison test. $\mathrm{P}<0.05$ compared to the control group.

\section{Discussion}

Results showed that there was a significant difference between $\mathrm{Hb} \mathrm{H}$ disease patients and the normal patients as well as beta thalassemia major patients and control group $(\mathrm{p}<0.05$, Dunnett's multiple comparison test). $\mathrm{Hb} \mathrm{H}$ disease patients could develop iron overload without transfusion. The causes of developing iron overload are possibly due to the ineffective erythropoiesis, increased iron absorption in the intestine and decreased serum hepcidin Liu et al. (2016). Our previous pilot study indicated higher leucocytic DNA damage in alpha and beta thalassemia patients Szeto \& Chan (2021).

Iron mediates Fenton's reaction and lead to the formation of hydroxyl radical $(\cdot \mathrm{OH})$ in vivo. Hydroxyl radical is highly reactive to the DNA and causes DNA lesions. The increased chance of iron overload in thalassemia patients in turn contributes to higher cellular DNA damage. Results from current study supported the association between leucocytic DNA damage and thalassemia. Iron overload resulted from chronic frequent $\mathrm{RBC}$ transfusion often damages multiple organs including the heart and liver etc. ROS produced in multiple organs can cause damage and even organ failures Offer et al. (2015). It has been suggested iron chelation therapy can be used to treat iron overload in haemoglobinopathies, by reducing oxidative stress due to iron overload. Iron chelation therapy targets serum ferritin and iron levels Bou-Fakhredin et al. (2018). Chelation of intracellular iron has been shown to lower the DNA damage in lymphocytes in thalassemia patients Shaw et al. (2017). Myelodysplastic syndrome patients are found to have higher oxidative stress Saigo et al. (2014) which is the result of high iron uptake and chronic transfusion therapy Gattermann (2017). The resulted oxidative stress may further contribute to the genetic instability in bone marrow Westhofen et al. (2015). Lowering iron level by chelation has been suggested crucial in reducing the risk of cancers Coates et al. (2016).

\section{CONCLUSION}

To conclude, both $\mathrm{Hb} \mathrm{H}$ disease and $\beta$ thalassemia major patients showed higher DNA damage in leukocytes the normal group which might be due to iron overload.

\section{ACKNOWLEDGMENT}

The authors would like to thank Tuen Mun Hospital and Macao Society for the Study of Women's Health for the supporting of this study.

\section{REFERENCES}

Angastiniotis, M., \& Lobitz, S. (2019). Thalassemias: an overview. Int J Neonat Screen. 5, 16.

Bain, B., Bates, I., Laffan, M., \& Lewis, S. (2011). Dacie and Lewis Practical Haematology. $11^{\text {th }}$ ed. London: Churchill Livingstone.

Bou-Fakhredin, R., Elias, J., \& Taher, A. T. (2018). Iron overload and chelation therapy in hemoglobinopathies. Thal. Rep. 8, 7478.

Brancaleoni, V., Di Pierro, E., Motta, I., \& Cappellini, M. (2016). Laboratory diagnosis of thalassemia, Int $J$ Lab Hemat. 38, 32-40.

Chen, F. E., Ooi, C., Ha, S. Y., Cheung, B., Todd, M. D. Liang, R. T., et al. (2000). Genetic and clinical features of hemoglobin $\mathrm{H}$ disease in Chinese patients. N Engl J Med. 24: 544-550.

Coates, T. D., Carson, S., Wood, J. C., \& Berdoukas, V. (2016). Management of iron overload in hemoglobinopathies: what is the appropriate target iron level? Ann NY Acad Sci. 1368, 95-106.

Gattermann, N. (2017). Iron overload in myelodysplastic syndromes (MDS), Int $J$ Hemat.107, 55-63.

Hoffbrand, A. V., \& Moss P. A. H. (2016). Hoffbrand's Essential Haematology. $7^{\text {th }}$ ed. West Sussex: Wiley-Blackwell.

Liu, R. R., Huang, Y. M., Peng, P. P., Wei, X. Y., Lei, Y., Liu, J. D. et al. (2016). Iron overload status in patients with non-transfusion-dependent thalassemia in China. Blood, 128, 1287.

Offer, T., Bhagat, A., Lal, A., Atamna, W., Singer, S.T., Vichinsky, E.P. et al. (2005). Measuring chromosome breaks in patients with thalassemia. Ann NY Acad Sci.1054, 439-444.

Osipov, A., Arkhangelskaya, E., Vinokurov, A., Smetanina N., Zhavoronkov, A., \& Klokov, D. (2014). DNA comet Giemsa staining for conventional bright-field microscopy. Int J Mol Sci. 15, 6086-6095.

Piel, F. B., \& Weatherall, D. J. (2014). The $\alpha$-thalassemias. $N$ Eng J Med. 371, 1908-1916.

Saigo, K., Takenokuchi, M., Hiramatsu, Y., Tada, H., Hishita, T., Takata, M., et al. (2011). Oxidative stress levels in myelodysplastic syndrome patients: their relationship to serum ferritin and haemoglobin values. $J$ Int Med Res. 39, 1941-1945.

Shaw, J., Chakraborty, A., Nag, A., Chattopadyay, A., Dasgupta, A. K. \& Bhattacharyya, M. (2017). Intracellular iron overload leading to DNA damage of lymphocytes and immune dysfunction in thalassemia major patients. Eur J Haemat. 99, 399-408.

Szeto, Y. T., \& Chan, C. Z. C. (2021). Association between thalassemia and leucocytic DNA damage: a pilot study. J Basic App Res Biomed. 7, 2426.

Tari, K., Ardalan, P. V., Abbaszadehdibavar, M., Atashi, A., Jalili, A., Gheidishahran, M. (2018). Thalassemia an update: molecular basis, clinical features and treatment", Int J Biomed Pub Heal. 1, 48-58.

Westhofen, G., Ganster, C., Beier, F., Rassaf, T., Al-Ali, H. K., Stuhlmann, R., et al. (2015). Comprehensive genomic analysis provides further evidence that iron overload can induce genetic instability in myelodysplastic syndromes. Blood. 126, 2842. 